\title{
Interest Rate Risk Management for Commercial Banks in Kenya
}

\author{
${ }^{1}$ James Ngalawa, ${ }^{2}$ Philip Ngare \\ ${ }^{1}$ Catholic University of East Africa, Kenya \\ ${ }^{2}$ University of Nairobi, Kenya
}

\begin{abstract}
We show empirically that bank's exposure to interest rate risk or income gap determines the structure of the balance sheet. In particular, we show that in Kenya, commercial banks typically retain a large exposure to interest rates that can be predicted through the income gap. We also establish the sensitivity of income gaps to market interest rates as determined by the Central Bank of Kenya (CBK) through treasury instruments. Quantitatively, a 200 basis point change in CBK rates would lead to a change of net income equivalent to $0.4 \%$ of total assets of the bank.
\end{abstract}

JEL Classification: G12, G21

Keywords: Interest rate risk, risk management, commercial banks in Kenya, Basel capital accord, income gap analysis.

\subsection{Background}

\section{Introduction}

Over the past few years both banking supervisors and researchers have nearly exclusively focused their attention on banks' credit and operational risk, and most recently, considerable attention is now being turned on interest rate risk. One reason for this is its threat to the stability of the financial system as a kind of systematic risk. In 2004, the Basel Committee on Banking Supervision (2004b) suggested 'Principles for the Management and Supervision of Interest Rate Risk' that go far beyond current practice. Within these principles the committee states that "this (interest rate) risk is a normal part of banking and can be an important source of profitability" but stresses that it is "essential to the safety and soundness of banks" that interest rate risk is maintained within prudent levels.

In order to apply a comparable and widely accepted measure for the interest rate risk of banks, we follow the "standardized interest rate shock" approach also proposed within the new Basel Capital Accord (Basel II), that are published by the Basel Committee on Banking Supervision (2004). The committee recommends that supervisors to be particularly attentive to those banks (outlier banks) whose regulatory capital declines by more than $20 \%$ when a 200 basis point interest rate shock occurs.

We seek to establish whether in emerging markets such as Kenya, where interest rate volatility is relatively high and the economy highly sensitive to movement in global factors, how net interest margins change with market rates. We investigate the empirical relationship between market interest rates and the banks flow of net interest income \& expense among publicly listed commercial banks in Kenya. We contribute and compliment literature through documenting empirically the exposure of commercial banks in Kenya to interest rate risks as well as show that income gap predicts interest rate risk.

By looking at the actual behavior of interest income and expense as well as net interest margins, one can see whether sharp movements in market rates or typical configurations of long and short-term interest rates have had large effects on bank's net interest income. This evaluation implicitly takes account of the way that banks have chosen to adjust the pricing of their assets and liabilities as well as the actual behavior of bank customers with regard to prepayments and early withdrawals.

Because there is still no standardized access to banks' internally quantified interest rate risk, most models proposed in the literature and applied by banking supervisors rely on accounting based data. These include Bennett et al. (1986), Planta (1989), Patnaik and Shah (2004), and the Federal Reserve's Economic Value Model (EVM) presented by Houpt and Embersit (1991) and analyzed by Wright and Houpt (1996), Sierra (2004), and Sierra and Yeager (2004), as well as the 'standardized framework' suggested by the Basel Committee on Banking Supervision (2004).

We analyze interest rate sensitivity gaps obtained from financial reports for 10 commercial banks listed in the Nairobi securities exchange for the period 2008-2012. The rest of the paper is organized as follows; Section 2 reviews related studies on interest rate risk and related literature, section 3 shows the methodology used and the model relied upon in this study, section 4 discusses and analyses data and results of the study, section 5 concludes and makes recommendations for further research. 


\subsection{Objectives of the study}

1. To undertake a quantitative assessment of the interest rate risk faced by commercial banks in Kenya.

2. To establish the relationship between interest rate sensitivity gap and market interest rates.

3. To investigate the techniques used for measuring \& managing interest rate risks by commercial banks in Kenya.

\subsection{Significance of the study}

It is essential that banks have comprehensive risk management processes in place that effectively identifies, measures, monitors and controls interest rate exposures and that is subject to appropriate board and senior management oversight.

The study will assist commercial banks in Kenya (and emerging economies) evaluate the adequacy \& effectiveness of interest rate risk management measures adopted.The study will also be useful in strengthening the supervisory authorities' framework in dealing with interest rate risk exposures by commercial banks.

\subsection{Statement of the problem}

Following the global economic crisis in 2008, which led to the collapse of several financial institutions, there is a heightened emphasis on risk management practices in financial institutions in the world. Banks and their supervisors have spent considerable time and effort in recent years developing systems for monitoring and managing interest rate risk (BCBS 2001).Unfortunately, there is little data available concerning the interest rate risk for banks. Also, there are limited comprehensive empirical studies, particularly in emerging markets, that critically analyze the interest rate risk exposures of commercial banks as well as quantitative approaches of evaluating interest rate risk.

\subsection{Scope of the Study}

Analysis of interest rate sensitivity gap used in previous related studies will be relied upon to evaluate the interest rate risk exposure. The scope of the study will be limited to the public listed commercial banks in Kenya. Secondary data will be collected relating to interest rate risk evaluation.

\section{Literature Review}

In light of the uncertain course of interest rates, financial intermediaries face significant challenges in managing their interest rate exposures. Clearly, the impact of changes in market rates depends on the maturity and re-pricing mismatches embedded in institutions' assets, liabilities, and off-balance-sheet positions. In general, those institutions whose assets are expected to re-price faster than their liabilities--referred to as "assetsensitive"--would be expected to benefit from a rise in rates, because higher rates, holding everything else constant, should increase their net interest margins. Conversely, the net interest margins of "liability sensitive" institutions--those whose asset durations are longer than their liability durations--would be expected to be negatively affected by a rise in market interest rates (Kohn, 2010).

The high and volatile nominal interest rates associated with contemporary inflation have prompted a pronounced change in commercial banks balance sheet.Low cost deposits have been replaced by alternative funding vehicles bearing high and increasingly variable interest rates (Budzeika 1980, Kane 1979\& Silber 1977) In an apparent adaptive response to the loss of deposits, banks have eschewed fixed rate loans in favor of variable lending, thereby more closely matching the durations of their assets and liabilities (Flannery 1981, Boltz\& Campbell 1979). This change in bank lending practices has been popularly interpreted as an effort to "immunize" cash-flows in the face of increased interest rate uncertainty (Haley 1981,\&Wojnilower 1980).

Apart from Niehans\&Hewson, (1976) the adaptive re-composition of bank balance sheets has not been formally addressed. Deshmukh et al (1983) provide a model of balance sheet duration matching and show that an increase in interest rate volatility is likely to lead a bank to choose a balance sheet that is more closely matched.

Balance sheet mismatching can be understood in terms of the two basic functions of financial intermediaries: Brokerage and asset transformation. A broker joins borrowers and lenders without assuming any risk.Asset transformation necessitates balance sheet mismatching which in turn implies some type of risk for the intermediary. The choice of the mode of intermediary is influenced by uncertainty in loan demand and funds supply conditions.

Maturity transformation is often seen as a specific function of banks (e.g. Niehans, 1978): customers tend to borrow long-term capital and to lend short-term capital. Additionally, banks may have an incentive to lend out long-term and refinance short-term since the slope of the term structure is usually positive (e.g. Bhattacharya and Thakor, 1993): on average, long-term interest rates (for assets) exceed the short-term interest rates (for liabilities). Thus, on average, the bank achieves a premium from maturity transformation. On the other 
hand, the resulting maturity mismatch between the assets and liabilities causes interest rate risk. While there is the incentive to bear interest rate risk due to the expected yield, there are several economic reasons why firms should manage and limit their risks (e.g. Allen and Santomero, 1998). These include managerial self-interest (Stulz, 1984), non-linearity of taxes (Smith and Stulz, 1985), costs of financial distress (Warner, 1977) and capital market imperfections (Froot et al., 1993; Froot and Stein, 1998).

We expect that smaller banks have a higher incentive to keep their exposure to interest rate risk low than bigger banks for several reasons: first, bigger banks may be assumed to be "too big to fail" by their investors and other stakeholders and hence face lower financial distress costs (e.g Saunders et al., 1990). Second, bigger banks are more diversified than smaller banks and hence have a lower level of idiosyncratic risk. To obtain a certain level of total risk, these banks may bear more systematic (interest rate) risk (e.g. Demsetz and Strahan, 1997). Third, the information risk may be lower for investors of bigger banks and hence may be substituted by interest rate risk (e.g. Banz, 1981). Fourth, bigger banks may have more opportunities to trade their risk on the capital market and hence to alter their exposure to interest rate risk via off-balance sheet activities quickly, once a stress situation occurs.

An historical example of a banking crisis where interest rate risk played an integral role is the 'Savings and Loan Crisis' which occurred in the US during the 1980s. Between 1980 and 1988, where 563 of the approximately 4,000 then existing savings and loan institutions failed, while further failures were prevented by 333 supervisory mergers. The total costs of the crisis are estimated at USD $160 \mathrm{bn}$. (Federal Deposit Insurance Corporation, 1997)

Few comprehensive empirical studies have been carried out in emerging markets on how commercial banks control for interest rate volatility. This paper will attempt to quantitatively and comprehensively assess and measure the exposure to interest rate risk for listed banks in Kenya, as well as study how they manage the volatility in interest rates.

\subsection{Sources of Interest rate risk}

Interest rate risk is the exposure of an institutions financial condition to adverse movements in interest rates. Some of the common sources of interest rate risk include;

\section{Re-pricing risk}

The primary and most often discussed form of interest rate risk arises from timing differences in the maturity (for fixed rate) and re-pricing (for floating) of assets, liabilities and off-balance sheet (OBS) positions. While such re-pricing mismatches are fundamental to the business of banking, they can expose a banking institution's income and underlying economic value to unanticipated fluctuations as interest rates vary.

\section{Yield curve risk}

Re-pricing mismatches can also expose a banking institution to changes in the slope and shape of the yield curve. In finance, the yield curve is a curve showing several yields or interest rates across different contract lengths ( $2 \mathrm{mths}, 2 \mathrm{yrs}, 20 \mathrm{yrs}$ etc) for a similar debt contract. The curve shows the relation between the (level of) interest rate (or cost of borrowing) and the time to maturity, known as the term of the debt for a given borrower in a given currency.

Formal mathematical descriptions of this relation are often called term structure of interest rate. Yield curves are used by fixed income analysts, who analyze bonds and related securities, to understand conditions in financial markets and to seek trading opportunities. Economists use the curves to understand economic conditions.

\section{Basis risk}

This arises from imperfect correlation in the adjustment of the rates earned and paid on different instruments with otherwise similar re-pricing characteristics. When interest rates change, these differences can give rise to unexpected changes in the cash flow and earnings spread between assets and liabilities and OBS instruments of similar maturities or re-pricing frequencies.

\section{Optionality risk}

An additional and increasingly important source of interest rate risk arises from the options embedded in many banking institutions assets, liabilities and OBS position. Instruments with embedded options are generally most important in non-trading activities. They include various types of bonds and notes with call or put provisions, loans which give the borrowers the right to prepay balances and various types of non-maturity deposits instruments which give the depositor the right to withdraw funds at anytime, often without penalties.

If not adequately managed, the asymmetrical payoff characteristics of instruments with optionality features can pose significant risk particularly to those who sell them, since the options held, both explicit and 
embedded are generally exercised to the advantage of the holder and the disadvantage of the seller. Moreover, an increasing array of options can involve significant leverage which can magnify the influences (both negative and positive) of option positions on the financial conditions of the firm.

The approach used in this paper will mainly focus on re-pricing risk in commercial banks in Kenya which is the most common interest risk among all the banks with interest income contributing significantly to the profitability of the bank.

\subsubsection{Risk Measurement, Monitoring and Management Information System}

Interest rates can have adverse effects both on a banking institutions earnings and its economic value. This has given rise to several perspectives for assessing interest rate risk exposure;

\section{Earnings Perspective}

The focus of analysis is the impact of change in interest rate on accrual or reported earnings. This is the traditional approach. Reduced earnings or outright losses can threaten the financial stability of an institution by undermining its capital adequacy and reducing market confidence.

The component of earnings that has traditionally received the most attention is net interest income (Interest Income-Interest exposure). The percentage net interest income to the total income of the bank, would suggest the extend of the exposure to interest rate risk.

\section{Economic Value Perspective}

Variation in market interest rates can also affect the economic value of a banking institution's assets, liabilities and OBS positions. The economic value of an instrument represents an assessment of the present value of its expected net cash flows, discounted to reflect market rates.

The economic value perspective reflects one view of the sensitivity of the net worth of the banking institution to fluctuations in interest rates. Since the economic value perspective considers the potential impact of interest rate changes on the present value of all future cash flows, it provides a more comprehensive view of the potential long term effects of changes in interest rates than offered by the earnings perspective.

\section{Embedded losses}

When evaluating the level of interest rate risk a banking institution is willing and able to assume, it should consider the impact that past interest rates may have on future performance. In particular, instruments that are not marked to market may already contain embedded gains or losses due to past rate movements. These gains or losses may be reflected over time in the banking institutions earnings.

An example would be, a long term fixed rate loan entered into when interest rates were low and re-funded more recently with liabilities bearing a higher rate of interest will over its remaining life represent a drain on the banking institutions resources.

This paper considers the economic value perspective and seeks to establish the interest risk exposure though determination of changes in Net Interest Income with changes in market interest rates.

Measurement systems should observe the following

1. Asses all material interest rate risks associated with a banking institution's assets, liabilities and OBS positions.

2. Utilize generally accepted financial concepts and risk measurement techniques.

3. Have well documented assumptions and parameters.

Interest rate characteristics of a banking institutions largest holding will dominate its aggregate risk profile.

\subsubsection{Measurement Techniques}

\section{Gap Analysis}

The simplest technique for measuring interest rate risk exposure begins with a maturity/re-pricing schedule that distributes interest-sensitive assets, liabilities and OBS positions into time bands according to their maturity (if fixed rate) or time remaining to their next re-pricing (if floating rate)

The schedule can be used to generate simple indicators of the interest rate risk sensitivity of both earnings and economic value to changing interest rates. When this approach is used to assess the interest rate risk of current earnings, it is typically referred to as Gap Analysis. The size of the gap for a given time band gives an indication of the banking institutions re-pricing risk exposure.

2.

\section{Duration}

This is a measure of the percentage change in the economic value of a position that will occur given a small change in the level of interest rates. A maturity/repricing schedule can be used to evaluate the effect of 
changing interest rates on a banking institutions economic value by applying sensitivity weights to each time band.

Typically such weights are based on estimates of the duration of the assets and liabilities that fall into each time-band. Duration-based weights can be used in combination with a maturity/repricing schedule to provide a rough approximation of the change in banking institutions economic value that would occur given a particular set of changes in market interest rates.

\section{Simulation techniques}

These involve detailed assessments of the potential effects of changes in interest rates on earnings and economic value by simulating the future path of interest rates and their impact on cash flows.

This investigation uses Gap analysis to evaluate the exposure of commercial banks in Kenya to interest rate risk. The objective of this investigation is to quantitatively evaluate the interest rate risk among commercial banks in Kenya and it relationship with market rates. Annual reports are relied upon for data which have adequate information to evaluate the objectives using gap analysis.

\subsection{Interest rate risk and bank net interest margins}

Banks and their supervisors have spent considerable time and effort in recent years developing systems for monitoring and managing interest rate risk. We examine that specific component of interest rate risk arising from the possible effects of changes in market interest rates on bank net interest margins. Such effects can be very large if interest rate risk is not managed carefully. For example, the secondary banking crisis in the United Kingdom in the 1970s reflected, at least in part, the funding of longer-term assets with short-term liabilities. Similarly, funding of long-term, fixed rate mortgages with savings deposits led to a very sharp drop in net interest margins at US thrift institutions in the early 1980s when interest rates rose to historic highs and the yield curve inverted. The result was actually negative net interest income for two years at US thrifts, after net interest margins had averaged nearly $1.5 \%$ over the preceding decade (FHLBB (1984)).

By contrast, the results from a study by English (2002) suggest that commercial banks in the 10 industrial countries considered have generally managed their exposures to volatility in the yield curve in ways that have limited effects on their net interest margins. Thus, while fluctuations in net interest margins could be an important source of uncertainty in bank profitability - and could surely have adverse effects for particular institutions - changes in interest rates seem unlikely to undermine sharply the health of the banking sector through their effects on net interest income.

\subsection{Assessing Interest rate risk}

To assess directly the extent of a bank's interest rate risk would require detailed information about a number of possible sources of interest rate risk. Clearly, one would need information on the pricing of the bank's assets and liabilities, including re-pricing periods and base rates. Moreover, this data would need to be supplemented by information on the adjustments that the bank is likely to make to the rates on assets and liabilities that it can re-price at its discretion following changes in market rates. One would also require information on the likelihood that bank customerswould choose to repay loans or withdraw funds early as a result of changes inmarket rates. Finally, one would need information sufficient to allow anevaluation of other potential sources of interest rate risk, including the interestsensitivity of fee income and off-balance sheet exposures.

In addition to its inherent complexity, such a direct approach is difficult forthe researcher to implement because the necessary information is lacking.There is a paucity of data on the re-pricing intervals of banks' assets andliabilities. In addition, while there has been considerablestudy of the pricing of some types of deposits and loans, such information ishardly complete. Finally, the extent to which bank customers take advantageof the options embedded in some bank contracts is generally hard to assessbecause of a lack of data on such behavior.

As a result of these difficulties, a simpler approach is taken in this paper, focusing on the empirical relationships between market interest rates and banks' flows of interest income and expense. By looking at the actual behavior of interest income and expense, as well as net interest margins, one can see whether sharp movements in market rates or typical configurations of long and short-term interest rates have had large effects on banks' net interest income. Moreover, this evaluation implicitly takes account of the way that banks have chosen to adjust the pricing of their assets and liabilities, as well as the actual behavior of bank customers with regard to prepayments and early withdrawals.

This approach leaves aside other possible sources of interest rate risk, including effects of interest rates on fee income, trading income and off-balance sheet exposures. In particular, to the extent that banks hedge the interest rate risk associated with their net interest income using derivatives such as swaps, the effects of their hedging may be missed. Nonetheless, it seems likely that much of banks' interest rate risk reflects mismatches 
on their balance sheet, and understanding this portion of banks' interest rate risk is a useful first step towards a broader assessment.

This approach is implemented in two steps. First, the empiricalrelationships between the average yield on bank assets and the average costof bank liabilities, on the one hand, and short-term and long-term market rates,on the other, are estimated. In particular, these relationships are examined tosee if they are consistent with significant differences in the average re-pricingintervals of bank assets and liabilities. Then the slope of the yield curve andchanges in market rates are tested to see if they appear to be related to banks'net interest margins.

\subsection{Model}

\section{Methodology}

In order to apply a comparable and widely accepted measure for the interest rate risk of banks, we follow the 'standardized interest rate shock' approach also proposed within the new Basel Capital Accord (Basel II) and the 'Principles for the Management and Supervision of Interest Rate Risk' that are published by the Basel Committee on Banking Supervision (2004a, b).

Definition (Interest Rate Risk): The interest rate risk (IRR) of a bank is given by the maximum absolute change of its economic value caused by an upward and downward 200 basis point parallel interest rate shock in relation to its regulatory capital.

Approximating the interest rate sensitivity by duration, the interest rate risk of a bank in $\mathrm{t}_{\text {ref }}$ ("reference date") is measured by:

$$
\operatorname{IRR}\left(t_{r e f}\right)=0.02\left|\frac{\sum_{t_{C F}>t_{r e f}}\left(t_{C F}-t_{r e f}\right) \frac{\sum_{p o s \in P O S^{A}} C F\left(p o s, t_{r e f}, t_{C F}\right)-\sum_{p o s \in P O S^{L}} C F\left(p o s, t_{r e f}, t_{C F}\right)}{\left(1+R_{a c}\left(t_{r e f}, t_{C F}\right)\right)^{\left(t_{C F}-t_{r e f}+1\right)}}}{R C\left(t_{r e f}\right)}\right|
$$

$R C\left(t_{r e f}\right)$ denotes the regulatory capital in $t_{r e f} \cdot P O S^{A}$ is the set of all interest rate-sensitive asset positions, $P O S^{L}$ the set of all interest rate-sensitive liability positions and $t_{C F}$ the set of all points in time when cash flows are due. $C F\left(\operatorname{pos}, t_{r e f}, t_{C F}\right)$ denotes the cash flow of position posin $t_{C F}>t_{\text {ref }}$ from the perspective of $\mathrm{t}_{\text {ref }}$ (The cash flow due in $t_{C F}=t_{\text {ref }}$ does no influence the bank's interest rate risk and is hence omitted). The set of all $C F\left(p o s, t_{r e f}, t_{C F}\right)$ will be referred to as 'cash flow structure'. Finally, $R_{a c}\left(t_{r e f}, t_{C F}\right)$ represents the annually compounded spot rate in $t_{r e f}$ for the date, $t_{C F}$. In line with the earlier accounting-based models (See Section 1) we only capture here the interest rate risk of the net portfolio value, excluding other components such as the exposure of the going concern value (See Samuelson, 1945).

The key to the analysis is determining the detailed cash flow structure in equation (1) that is usually unknown to regulators, external analysts and a bank's stake holders.

Gap reports are commonly used to assess and manage interest rate risk exposure specifically, a bank's re-pricing and maturity imbalances. Although a simple gap report does not identify and quantify basis risk, yield curve risk, and option risk, bankers have modified gap reports to do so. Gap reports stratify all of a bank's assets, liabilities, and off-balance-sheet instruments into maturity segments (time bands) based on the instrument's next re-pricing or maturity date. Balances within a time band are then summed (assets are reported as positive amounts and liabilities as negative amounts) to produce a net gap position for each time band. Risk is measured by the size of the gap (the amount of net imbalance within a time band) and the length of time the gap is open.

Using properly prepared gap reports, a bank can identify and measure short- and long-term re-pricing imbalances. With this information, a bank can estimate its earnings and economic risks within certain constraints. Gap reports can be particularly useful in identifying the re-pricing risk of a bank's current balance sheet structure before assumptions are made about new business or how to effectively reinvest maturing balances. 
There are 10 listed commercial banks in Kenya, BBK, CFC-Stanbic, DTB, Equity, HF, KCB, NBK, NIC, SCB \& Co-op Bank.Gap reports were constructed from their published audited accounts for the last 5 years ( ${ }^{\text {st }}$ Jan $2008-31^{\text {st }}$ Dec 2012).

Interest rate sensitivity for each of the banks will be correlated to the following industry rates;

1. Interbank rate

2. $\quad$ T-bill rate $(91,181, \& 364$ days $)$

We shall seek to establish if there exists any correlation between the observed interest rate gaps and the above industry rates.

After a bank has stratified the bank's assets, liabilities, and off-balance-sheet instruments into time bands and determined how it will treat embedded options, it must measure net interest income (NII) at risk. The formula to translate gaps into the amount of net interest income at risk, measuring exposure over several periods, is:

$\Delta N I I=($ periodic gap $) \times($ change in rate $) \times($ time over which the periodic gap is in effect $)$

Net Income sensitivity calculations will be modeled assuming a 200 basis point change in interest rates and establish the net effect on the banks earnings.

3.1.1 Regression Model

To determine the sensitivity of Interest rate risk proxied by change in Net interest income, to market rates and size of bank assets, we follow the linear model below;

$$
\operatorname{IRR}(\Delta N I I)=\beta_{0}+\beta_{1} \delta T B_{91}+\beta_{2} \delta T B_{181}+\beta_{3} \delta T B_{364}+\beta_{4} \delta \text { IntBank }+\beta_{5} \delta L \text { og Assets }
$$

Where $I R R(\Delta N I I)$ represent Interest Rate Risk proxied by change in Net Interest Income. $\delta T B_{91}$ represents the standard deviation in CBK 91 days Treasury Bill rate, $\delta T B_{181}$ represents the standard deviation in CBK 181 days T-Bill rate, $\delta T B_{364}$ represents the standard deviation in CBK364 days T-bill rate, $\delta$ IntBank represents the standard deviation in the inter-bank rate. LogAssets represents the size of the bank.

The standard deviations of the market rates represent the volatility of the interest rates in the Kenyan market that dictate the matching of balance sheets by commercial banks in the country.

\subsection{Sample}

\section{Data Analysis And Results}

There are 11 listed commercial banks in the Nairobi securities exchange. One of the banks I\&M bank was listed in 2012 and as such has no adequate data for comparison purposes. CFC-Stanbic bank does not disclose provide gap report analysis in their annual reports and thus could not be included in the sample. We were not able to obtain all the annual reports for Barclays bank Kenya, Co-op Bank \& National bank of Kenya for the entire 5yr period and thus did not include them in the sample. Complete data was available for six of the banks which have been relied upon for this investigation. (See, Table 4.1-4.6).

\subsection{Market Interest rates}

Data from the Central Bank of Kenya (available on the website) was relied upon to determine the market interest rates. Treasury bill rates for 91 days, 182days \& 364days were relied upon to determine the effect of market interest rates on re-pricing gaps and by extension interest rate risk exposure for the various commercial banks listed in the NSE. Data for the period 2008-2012 was relied upon. The standard deviations for the T-Bill rates was relied upon to approximate the volatility in the markets rates.

\subsection{Data Analysis}

Table 4.7 represents computations for Net Interest income for 6 commercial banks listed in the NSE as well as the log of total assets of the bank used to proxy the size of the bank. The standard deviations of the market rates proxied use the CBK short Term rates of T-Bills 91,181\& 364days. Net interest Income has been computed using the equation (2) referred to earlier. This takes in to account the weighted size and duration of assets and liabilities in the respective gap periods represented in the gap reports.

Below is a summary of the key parameters statistics used to model the relationship between interest rate exposure and market interest rates. It can be observed that the banking industry in Kenya is generally asset sensitive suggested by the positive figure for Net interest income sensitivity gap of 0.00395 standardized by total assets of the bank. This implies that a $2 \%$ change in interest rates results to a change of income equivalent to $0.4 \%$ of total assets of the bank.

Table 1.Descriptive statistics

\begin{tabular}{|l|l|l|}
\hline Mean & Std. Deviation & $\mathrm{N}$ \\
\hline
\end{tabular} 


\begin{tabular}{|l|l|l|l|}
\hline NII & .00394547 & .047889104 & 30 \\
LogAssets & 4.91458537 & .354779234 & 30 \\
SD91 & 2.59361122 & 2.163129720 & 30 \\
SD181 & 2.52401673 & 2.087507668 & 30 \\
SD1yr & 2.98122736 & 1.901444186 & 30 \\
SDIntBank & 3.48054348 & 3.334828621 & 30 \\
\hline
\end{tabular}

Also we observe that Inter-bank lending rate has the highest volatility as suggested by the high standard deviation compared to Treasury bill rates. Modeling the above parameters according to the regression equation(3)referred to earlier, we obtain the model summary below;

Table 2.Model Summary

\begin{tabular}{|l|l|l|l|l|l|l|l|l|l|}
\hline Model & $\mathrm{R}$ & R Square & $\begin{array}{l}\text { Adjusted } \\
\text { R Square }\end{array}$ & $\begin{array}{l}\text { Std. } \\
\text { Error of } \\
\text { the } \\
\text { Estimate }\end{array}$ & $\begin{array}{l}\text { Change } \\
\text { Statistics }\end{array}$ & $\begin{array}{l}\text { Durbin- } \\
\text { Watson }\end{array}$ & & & \\
\hline & & & & $\begin{array}{l}\text { R Square } \\
\text { Change }\end{array}$ & F Change & df1 & df2 & $\begin{array}{l}\text { Sig. F } \\
\text { Change }\end{array}$ & \\
\hline 1 & $.267^{\mathrm{a}}$ & .071 & .122 & .0507 & .071 & .369 & 5 & 24 & .865 \\
\hline
\end{tabular}

In Table 2, we report an adjusted $\mathrm{R}$ square of 0.122 for the model. This may be considered satisfactory considering that the sample used was for 6 commercial banks in Kenya out of 44 registered commercial banks in Kenya. We suggest a more extensive sample of banks and possibly over a period of 10 years to be able to test the explanatory power of the model.

From the correlation of the model parameters, Table 3, there is a significant correlation between LogAssets and all the market interest parameters except the Treasury bill rate for the 1year bond. This suggests that the size of the balance sheet of the bank is greatly influenced by the market interest rates.

Table 3. Correlations

\begin{tabular}{|l|l|l|l|l|l|l|l|}
\hline & & NII & LogAssets & SD91 & SD181 & SD1yr & SDIntBank \\
\hline Pearson Correlation & NII & 1.000 & -.024 & .115 & .124 & .000 & .082 \\
\hline & LogAssets & -.024 & 1.000 & .347 & .345 & .231 & .302 \\
\hline & SD91 & .115 & .347 & 1.000 & .998 & .864 & .953 \\
\hline & SD181 & .124 & .345 & .998 & 1.000 & .855 & .947 \\
\hline & SD1yr & .000 & .231 & .864 & .855 & 1.000 & .854 \\
\hline & SDIntBank & .082 & .302 & .953 & .947 & .854 & 1.000 \\
\hline Sig. (1-tailed) & NII &. & .450 & .272 & .258 & .499 & .333 \\
\hline & LogAssets & .450 &. & .030 & .031 & .110 & .052 \\
\hline & SD91 & .272 & .030 &. & .000 & .000 & .000 \\
\hline & SD181 & .258 & .031 & .000 &. & .000 & .000 \\
\hline & SD1yr & .499 & .110 & .000 & .000 &. & .000 \\
\hline N & SDIntBank & .333 & .052 & .000 & .000 & .000 &. \\
\hline & NII & 30 & 30 & 30 & 30 & 30 & 30 \\
\hline & LogAssets & 30 & 30 & 30 & 30 & 30 & 30 \\
\hline & SD91 & 30 & 30 & 30 & 30 & 30 & 30 \\
\hline & SD181 & 30 & 30 & 30 & 30 & 30 & 30 \\
\hline & SD1yr & 30 & 30 & 30 & 30 & 30 & 30 \\
\hline
\end{tabular}

\section{Conclusion And Recommendation}

This study, sought to establish the exposure to interest rate risk among commercial banks in Kenya. We have established from the sample of banks investigated that a $2 \%$ change in the market interest rates would result to a change in income equivalent to $0.4 \%$ of total assets of the bank. We also observed that most commercial banks listed in the NSE were asset sensitive.

We recommend a wider sample of banks over a longer time series period to establish a comprehensive effect of market interest risks on interest risk exposure of bank in Kenya. Similar studies have also investigated how exposure to interest rate risk affects prices in the stock exchange. A primary data collection exercise would be appropriate to understand how various banks hedge and mitigate the exposure to interest risk. Also it would be appropriate to test these results against a simulation method such as the Monte Carlo simulation method (MCSM) to establish the validity of the approach. Standard Charted bank has reported using the MCSM to analyze their IRR exposure.

\section{References}


[1]. Allen, F., Santomero, A. M., 1998.The theory of financial intermediation. Journal of Bankingand Finance 21 (11), $1461-1485$.

[2]. Banz, R. W., 1981. The relationship between return and market value of common stocks. Journalof Financial Economics 9 (1), 318.

[3]. Basel Committee on Banking Supervision (2004). Principles for the management and supervision of interest rate risk. Bank for International Settlements.

[4]. Basel Committee on Banking Supervision (2001): Principles for the management and supervision of interest rate risk, Bank for International Settlements, Basel, January.

[5]. Bennett, D. E., Lundstrom, R. D., Simonson, D. G., 1986. Proceedings - A Conference on Structure and Competition. Federal Reserve Bank of Chicago, Ch. Estimating Portfolio Net Worth Values and Interest Rate Risk in Savings Institutions, pp. 323-346.

[6]. Bhattacharya, S., Thakor, A. V., 1993.Contemporary banking theory. Journal of Financial

[7]. Intermedition $3(1), 2-50$.

[8]. Boltz, P, Campbell T.S, 1979. "Innovations in Bank Loan Contracting: Recent Evidence." Staff Studies 104 .Board of Governors of the Federal Reserve System.

[9]. Budzeika, G, 1980 "The Effect of Liability Management by Banks on their Lending Policies." Research Paper 8007 .Federal Reserve Bank of New York.

[10]. Demsetz, R. S., Strahan, P. E., 1997. Diversification, size and risk at bank holding companies. Journal of Money, Credit and Banking 29 (3), 300-313.

[11]. Deshmukh, S. D., Greenbaum, S. I., \&Kanatas, G. (1983).Interest rate uncertainty and the financial intermediary's choice of exposure. The Journal of Finance, 38(1), 141-147.

[12]. English, W. B. (2002). Interest rate risk and bank net interest margins. BIS Quarterly Review, 12(02), 67-82.

[13]. Flannery, M, 1981. "Market Interest Rates and Commercial Bank Profitability: An Empirical Investi-gation." Journal of Finance 36 - 1085-1101.

[14]. Federal Home Loan Bank Board (1984): Combined financial statements: FSLIC insured institutions, Washington, DC.

[15]. Federal Deposit Insurance Corporation, 1997. History of the eighties - lessons for the future.

[16]. Hodder, L. D., Hopkins, P. E., \&Wahlen, J. M. (2006). Risk-relevance of fair-value income measures for commercial banks. The Accounting Review, 81(2), 337-375.

[17]. Froot, K. A., Scharfstein, D. S., Stein, J. C., 1993. Risk management: Coordinating corporate

[18]. investment and financing policies. Journal of Finance 48 (5), 1629-1658.

[19]. Froot, K. A., Stein, J. C., 1998. Risk management, capital budgeting, and capital structure policy for financial institutions: An integrated approach. Journal of Financial Economics 47 (1), 55-82.

[20]. Haley, C, W, 1981. "Interest Rate Risk in Financial Intermediaries: Prospects for Immunization." Working Paper, University of Washington.

[21]. Houpt, J. V., Embersit, J. A., 1991. A method for evaluating interest rate risk in U.S. commercial banks. Federal Reserve Bulletin August, 625-637.

[22]. Kane, E. J, 1979. "The Three Faces of Commercial Bank Liability Management." In R. Lombra and H. Kaufman (eds.), The Political Economy of Policymaking. Sage Publications, pp. 149-74.

[23]. Kohn, D. L. (2010).Focusing on Bank Interest Rate Risk Exposure.Board of Governors of the Federal Reserve System.Päivitetty, $29,2010$.

[24]. Niehans, J, Hewson, J, 1976."The Eurodollar Market and Monetary Theory."Journal of Money, Credit and Banking 7 -1-27.

[25]. Memmel, C., Wilkens, M., \&Zeisler, A. (2008).Analyzing the interest rate risk of banks using time series of accounting-based data: Evidence from Germany. Deutsche Bundesbank.

[26]. Patnaik, I., Shah, A., 2004. Interest rate volatility and risk in Indian banking, IMF Working Paper, WP/04/17.

[27]. Planta, R., 1989. Controlling interest rate risk - the case of universal banks. Ph.D. Thesis, Hochschule St. Gallen, Bamberg, dissertation No. 1134.

[28]. Samuelson, P. A., 1945. The effect of interest rate increases on the banking system. American Economic Review 35 (1), 16-27.

[29]. Saunders, A., Strock, E., Travlos, N. G., 1990. Ownership structure, deregulation, and bank risk taking. Journal of Finance 45 (2), 643-654.

[30]. Sierra, G. E., 2004. Can an accounting-based duration model effectively measure interest rate sensitivity? Ph.D. thesis, Washington University in St. Louis.

[31]. Sierra, G. E., Yeager, T. J., 2004. What does the Federal Reserve's Economic Value Model tell us about interest rate risk at U.S. community banks? Federal Reserve Bank of St. Louis Review 86 (6), 45-60.

[32]. Silber, W, L, 1977. Commercial Bank Liability Management.Association of Reserve City Bankers.

[33]. Smith, C. W., Stulz, R., 1985. The determinants of firms' hedging policies. Journal of Financial and Quantitative Analysis 20 (4), 391-406.

[34]. Stulz, R., 1984. Optimal hedging policies. Journal of Financial and Quantitative Analysis 19 (2), $127-140$

[35]. Warner, J. B., 1977. Bankruptcy costs: Some evidence. Journal of Finance 32 (2), 337-347.

[36]. Wright, D. M., Houpt, J. V., 1996.An analysis of commercial bank exposure to interest rate risk. Federal Reserve Bulletin, $115-128$.

[37]. Wojnilower, A. M, 1980. "The Central Role of Credit Crunches in Recent Financial History."Brookings Papers on Economic Activity- 277-326.

\section{Appendix 1}

Table4.1. Ratio of Interest sensitivity Gap to Total assets for Diamond Trust Bank for the period 20082012 (Gap ratio GR)

\begin{tabular}{|l|l|l|l|l|l|l|}
\hline ASSETS & >1Mth & 1-3Mths & 4-12Mths & 1-5Yrs & >5yr & Zero Int \\
\hline GR 2008 & 0.3631 & $(0.1744)$ & $(0.1348)$ & $(0.0057)$ & 0.0000 & $(0.0481)$ \\
\hline GR 2009 & 0.3962 & $(0.1383)$ & $(0.3079)$ & 0.0499 & 0.0517 & 0.0620 \\
\hline GR 2010 & 0.2993 & $(0.0790)$ & $(0.2581)$ & 0.0680 & 0.0229 & 0.0705 \\
\hline GR 2011 & $(0.0499)$ & 0.4297 & $(0.1650)$ & 0.0566 & $(0.0001)$ & $(0.1503)$ \\
\hline GR 2012 & $(0.1626)$ & 0.5211 & $(0.1042)$ & 0.0243 & $(0.0001)$ & $(0.1351)$ \\
\hline
\end{tabular}

Table4.2. Ratio of Interest sensitivity Gap to Total assets for NIC Bank for the period 2008-2012 (Gap ratio GR

\begin{tabular}{|l|l|l|l|l|l|l|}
\hline ASSETS & >1Mth & 1-3Mths & 4-12Mths & 1-3Yrs & >3yr & Zero Int \\
\hline GR 2008 & 0.6023 & $(0.3833)$ & $(0.0289)$ & 0.0095 & 0.0063 & $(0.0778)$ \\
\hline GR 2009 & 0.6720 & $(0.3671)$ & $(0.0321)$ & 0.0180 & 0.0131 & $(0.1781)$ \\
\hline
\end{tabular}


Interest Rate Risk Management For Commercial Banks In Kenya

\begin{tabular}{|l|l|l|l|l|l|l|}
\hline GR 2010 & 0.6487 & $(0.2306)$ & $(0.1259)$ & 0.0242 & 0.0427 & $(0.0502)$ \\
\hline GR 2011 & 0.6325 & $(0.3235)$ & $(0.0695)$ & 0.0409 & 0.0354 & $(0.2063)$ \\
\hline GR 2012 & 0.5393 & $(0.1714)$ & $(0.0139)$ & 0.0339 & 0.0160 & $(0.2686)$ \\
\hline
\end{tabular}

Table4.3 Ratio of Interest sensitivity Gap to Total assets for Standard Chartered Bank for the period 2008-2012 (Gap ratio GR)

\begin{tabular}{|l|l|l|l|l|l|l|}
\hline ASSETS & $>$ Mth & $\mathbf{1 - 3 M t h s}$ & $\mathbf{4 - 1 2 M t h s}$ & $\mathbf{1 - 5 Y r s}$ & >5yr & Zero Int \\
\hline GR 2008 & 0.1208 & $(0.1076)$ & 0.0762 & 0.3012 & 0.0600 & $(0.3340)$ \\
\hline GR 2009 & 0.1391 & 0.0345 & 0.0932 & 0.0873 & 0.0549 & $(0.2923)$ \\
\hline GR 2010 & 0.1925 & 0.0355 & 0.0911 & 0.1653 & 0.0365 & $(0.3986)$ \\
\hline GR 2011 & $(0.1178)$ & 0.1319 & 0.1299 & 0.1971 & 0.1061 & $(0.3582)$ \\
\hline GR 2012 & 0.0074 & 0.0657 & 0.0583 & 0.2273 & 0.0916 & $(0.3047)$ \\
\hline
\end{tabular}

Table4.4 Ratio of Interest sensitivity Gap to Total assets for Equity Bank for the period 2008-2012 (Gap ratio $\mathbf{G R}$ )

\begin{tabular}{|l|r|r|r|r|r|}
\hline ASSETS & \multicolumn{1}{|c|}{ <3Months } & 3-6 Mths & $\mathbf{6 - 1 2}$ Mths & 1-5 yrs & over 5 yrs \\
\hline GR 2012 & $(0.556998)$ & 0.565678 & 0.407542 & 0.905681 & $(0.900951)$ \\
\hline GR 2011 & $(3.446294)$ & 0.078255 & 0.566860 & 0.908606 & $(0.429109)$ \\
\hline GR 2010 & $(0.056726)$ & 0.000738 & 0.782438 & 0.924915 & $(0.415014)$ \\
\hline GR 2009 & 0.518684 & $(0.126984)$ & 0.792654 & 0.944734 & $(1.543755)$ \\
\hline GR 2008 & 0.682070 & 0.608449 & 0.671372 & 0.925478 & $(2.652165)$ \\
\hline
\end{tabular}

Table4.5 Ratio of Interest sensitivity Gap to Total assets for KCB Bank for the period 2008-2012 (Gap ratio GR)

\begin{tabular}{|l|l|l|l|l|l|l|}
\hline ASSETS & >1Mth & 1-3Mths & 3-12Mths & 1-5Yrs & >5yr & Zero Int \\
\hline GR 2008 & $(0.478191)$ & $(0.013447)$ & 0.012775 & 0.235069 & 0.218736 & 0.025069 \\
\hline GR 2009 & $(0.525219)$ & $(0.021776)$ & $(0.059772)$ & 0.288269 & 0.257653 & 0.060844 \\
\hline GR 2010 & $(0.625380)$ & 0.043877 & $(0.005416)$ & 0.304208 & 0.283124 & $(0.000413)$ \\
\hline GR 2011 & $(0.492868)$ & $(0.071342)$ & $(0.032697)$ & 0.258388 & 0.300794 & 0.139459 \\
\hline GR 2012 & $(0.421664)$ & $(0.019717)$ & $(0.001969)$ & 0.178059 & 0.278571 & 0.106299 \\
\hline
\end{tabular}

Table4.6Ratio of Interest sensitivity Gap to Total assets for Housing Finance Bank for the period 20082012 (Gap ratio GR)

\begin{tabular}{|l|l|l|l|l|l|}
\hline ASSETS & Zero Int & <3Mths & 3-12Mths & 1-5Yrs & >5yr \\
\hline GR 2008 & 0.052930 & $(0.313808)$ & $(0.027535)$ & $(0.088594)$ & 0.416357 \\
\hline GR 2009 & $(0.356450)$ & $(0.334278)$ & $(0.182980)$ & 0.087981 & 0.648587 \\
\hline GR 2010 & $(0.143848)$ & $(0.061384)$ & $(0.185179)$ & 0.066420 & 0.223237 \\
\hline GR 2011 & $(0.199239)$ & $(0.174802)$ & $(0.208800)$ & 0.089852 & 0.332143 \\
\hline GR 2012 & $(0.166034)$ & 0.024291 & $(0.219824)$ & 0.065878 & 0.278801 \\
\hline
\end{tabular}

Table4.7 Net Interest Margins for 6 commercial banks listed in the NSE, log of their Total Assets and standard deviations for Market interest rates.

\begin{tabular}{|l|l|l|l|l|l|}
\hline & & & & \\
NII-BANKS & Log Assets & SD TB91 & SD TB 181 & SD TB1yr & SD Inter-bank \\
\hline$(0.045450)$ & 5.240789 & 4.537114538 & 4.202440489 & 3.931648875 & 5.872529010 \\
\hline$(0.053978)$ & 5.148782 & 5.623192976 & 5.543250537 & 5.851948549 & 8.772292123 \\
\hline 0.007673 & 5.030146 & 1.904322635 & 2.045373197 & 1.788277570 & .818018671 \\
\hline$(0.095686)$ & 4.876235 & .382250116 & .406100264 & .353034465 & 1.377607445 \\
\hline$(0.196044)$ & 4.767089 & .521175827 & .422919148 & & .562270155 \\
\hline 0.005992 & 4.962639 & 4.537114538 & 4.202440489 & 3.931648875 & 5.872529010 \\
\hline 0.007788 & 4.87816 & 5.623192976 & 5.543250537 & 5.851948549 & 8.772292123 \\
\hline 0.008174 & 4.758018 & 1.904322635 & 2.045373197 & 1.788277570 & .818018671 \\
\hline 0.010645 & 4.663522 & .382250116 & .406100264 & .353034465 & 1.377607445 \\
\hline 0.002757 & 4.61901 & .521175827 & .422919148 & & .562270155 \\
\hline 0.009350 & 5.020241 & 4.537114538 & 4.202440489 & 3.931648875 & 5.872529010 \\
\hline 0.009561 & 4.882023 & 5.623192976 & 5.543250537 & 5.851948549 & 8.772292123 \\
\hline 0.010935 & 4.757411 & 1.904322635 & 2.045373197 & 1.788277570 & .818018671 \\
\hline 0.007847 & 4.660239 & .382250116 & .406100264 & .353034465 & 1.377607445 \\
\hline 0.005600 & 4.615656 & .521175827 & .422919148 & & .562270155 \\
\hline 0.022203 & 5.269525 & 4.537114538 & 4.202440489 & 3.931648875 & 5.872529010 \\
\hline 0.021380 & 5.185230 & 5.623192976 & 5.543250537 & 5.851948549 & 8.772292123 \\
\hline 0.016881 & 5.125419 & 1.904322635 & 2.045373197 & 1.788277570 & .818018671 \\
\hline 0.013796 & 5.078370 & .382250116 & .406100264 & .353034465 & 1.377607445 \\
\hline 0.022152 & 4.981030 & .521175827 & .422919148 & & .562270155 \\
\hline 0.028335 & 5.542706 & 4.537114538 & 4.202440489 & 3.931648875 & 5.872529010 \\
\hline & & & & & \\
\hline
\end{tabular}


Interest Rate Risk Management For Commercial Banks In Kenya

\begin{tabular}{|l|l|l|l|l|l|}
0.032118 & 5.497876 & 5.623192976 & 5.543250537 & 5.851948549 & 8.772292123 \\
\hline 0.032227 & 5.400289 & 1.904322635 & 2.045373197 & 1.788277570 & .818018671 \\
\hline 0.029301 & 5.289540 & .382250116 & .406100264 & .353034465 & 1.377607445 \\
\hline 0.024333 & 5.281520 & .521175827 & .422919148 & & .562270155 \\
\hline 0.029930 & 4.589592 & 4.537114538 & 4.202440489 & 3.931648875 & 5.872529010 \\
\hline 0.033228 & 4.487294 & 5.623192976 & 5.543250537 & 5.851948549 & 8.772292123 \\
\hline 0.023233 & 4.452247 & 1.904322635 & 2.045373197 & 1.788277570 & .818018671 \\
\hline 0.062314 & 4.241322 & .382250116 & .406100264 & .353034465 & 1.377607445 \\
\hline 0.031769 & 4.135641 & .521175827 & .422919148 & & .562270155 \\
\hline 0.034779 & 5.226115 & 5.623192976 & 5.543250537 & 5.851948549 & 8.772292123 \\
\hline 0.028601 & 5.188487 & 1.904322635 & 2.045373197 & 1.788277570 & .818018671 \\
\hline 0.025129 & 5.044061 & .382250116 & .406100264 & .353034465 & 1.377607445 \\
\hline 0.024596 & 4.921614 & .521175827 & .422919148 & & .562270155 \\
\hline
\end{tabular}

